\title{
POWER IN INDONESIAN PRESIDENTIAL SPEECHES: AN ANALYSIS OF LINGUISTIC MODALITY
}

\author{
Siti Jannatussholihah [1], Sulis Triyono [2]
}

\author{
[1] jannatus88@gmail.com, [2] sulis@uny.ac.id \\ Yogyakarta State University \\ Yogyakarta, Indonesia
}

\begin{abstract}
This paper discusses the relationship between the language and power in the presidential speech text, which is projected through linguistic features, especially modalities. The data was obtained from a speech delivered by President Joko Widodo during the plenary session of the Indonesian People's Consultative Assembly (MPR RI) for the inauguration of the elected presidentfor the 2019-2024 period and the delivery of the president's vision for Indonesia better. Analysis of this paper from linguistic modalities uses a three-dimensional model of Fairclough's critical discourse (CDA) analysis to answer its research questions. The results show that Jokowi used several linguistic modal verbs in projecting his strength. Based on the modality's context, it can be understood that the president conveyed his strategic desire to be him self when he tried to connect with the audience and build his image, audience, and relationship. The President produces a discourse that embodies assumptions about his leadership and audience's social relationship and affirms his legal authority as president and his power. Through the language used, Jokowi creates, maintains, and expla in s power he holds in these forums.
\end{abstract}

Keywords: modality, critical discourse analysis, power, political speech, presidential speech

\section{INTRODUCTION}

Language is a medium for interaction in communication (Suryawinata, 1990, p. 2). As a communication medium, language is vital in the continuity of society. People understand that language is the basis of their social construction and their individual or group relationships. In this sense, language is seen as an instrument for consolidating and manipulating concepts and relationships in the field of power and control (Fowler, 1985, p. 61). Thus, certain written or spoken language style can come from various sources, such as cultural/social background, power, ideology, social status, or region.

Sornig (1989, p. 95) states that in political speeches, the process of expressing thoughts and conveying ideas does not only involve pure and unbiased statements. It involves concurrent cues of goals and desires, along with the message itself. Thus, some of the features of utterances in the speech events are focused on the elements surrounding them. Therefore, understanding the contextual environment is very important to understand these linguistic expressions.

The president's speech is one of the most exciting and widely analyzed political speeches because it contains the power struggle. Indonesia's seventh president, Joko Widodo, was re-elected for the second time. It is significant because it can offer an excellent opportunity to examine how he uses his powers in his speech.

Moreover, Chilton (2006, p. 3) proposes that politics is seen as a power struggle. From the linguistic point of view, one of the factors determining the success of political figures in achieving their goals and winning public support, especially in the continuous power 
struggle, is their ability to influence and persuade their audience through their speeches. Using the languages, politicians create, maintain, and replicate fundamental inequalities and asymmetries in society (Saville-Troike, 2003, p. 254).

One of how politicians project their power is through the use of linguistic modalities. In general, modality refers to the speaker's attitude or opinion about the validity of the arguments they express. Then, it also extends to the speaker's attitude towards the situation or event they are describing. Besides, modality is also related to how speakers and writers use language to express attitudes and beliefs, comment on, and emphasize their perspective.

Clark (2007, p. 151) states that modality, grammatically, is most commonly manifested through auxiliary modal verbs. Nuyts (2006, pp. 2-6) identifies three categories of modalities: dynamic, deontic, and epistemic. Meanwhile, in Indonesian modality, Alwi (1990) examines and classifie s Indonesian modalities into four subcategories, namely (a) intentional modality, (b) epistemic modality, (c) deontic modality, and (d) dynamic modality. Each subcategory is explored by showing the meaning and disclosing the modality. The meanings and disclosures of these modalities are described in the following sections.

This intentional modality is related to wishes, hopes, invitations, omissions, and requests. The wish consists of four levels, namely, desire, volition, intent, and childishness. The degree of desire can be expressed by ingin, mau, hendak, akan, bermaksud, and berhasrat. Meanwhile, hope (harapan) can be expressed by the modality harap, semoga, mudah-mudahan, and berdoa. Invitations can be expressed by ajak, mari, and ayo modalities. Allowance can be expressed by biar(lah) and biarkan(lah) modalities. In comparison, requests can be expressed with the modality of silakan, minta coba, sudilah, mohon, and tolong.

Epistemic modality usually involves an indication of the speaker's estimate of the likelihood of the state stated in the phrase or clause. In other words, it states the level of probability of a state, with several types of modality, namely probability, predictability, necessity, and certainty. Usually, epistemic modality is shown by the modality of dapat, bisa, bisa saja, bisa jadi, boleh, boleh saja, boleh jadi, and akan harus, pasti, yakin, and percaya. Epistemic modality reveals the level of the speaker's attitude towards the truth of an argument or proposition.

Moreover, the deontic modality is defined in terms of permits and obligations. In more general terms, the deontic modality can be defined as an indication of the state's level of moral desirability expressed in speech, but it usually does not have to be on the speaker's behalf. The expression of obligations, permits, and prohibitions can be considered more complicated because it involves assessing the level of moral acceptance of a state of affairs and the implementation of these assessments into action.

Meanwhile, dynamic modality is characterized as a perceived capacity or capability. This category is restricted to ability alone and includes an indication of the musts or needs of the participants. Thus, it includes the context inherent in the speaker and includes the context determined by local circumstances, such as capacity, ability, potential, and needs. The signifying elements can be lexical elements bisa, dapat, and татри.

This study explored the language used by the Indonesian president concerning power and language. It cannot be denie d that language is not always neutral. The use of language in political speech plays a vital role because it influences and reflects specific intentions, including reflecting or creating power. Power can be demonstrated and achieved through the use of language, although it is abstract. Therefore, the stu dy of politicians' language use in their political speeches can reveal the power projected in them.

Power is often demonstrated through language and can be achieved through it (Thomas \& Wareing, 2003, p. 10; SavilleTroike, 2003, p. 260; Reid \& Ng, 1999, p. 121). Moreover, Fairclough (1995, p. 1) reveals th at power is conceptualized both in discourse events, the asymmetry between participants or groups, and unequal capacities to control how texts are produced, distributed, and consumed in specific socio-cultural contexts. For example, political power can be expressed through the language used in political 
speeches or debates. Because the relationsh ip between language and power is dynamic and diverse, language must be examined in a social context. Language can create or reflect power can depend on the presence or absence of particular linguistic features. One of them is the power, which can be encoded in the expression of the modality.

By analyzing the linguistic modalities of political speeches delivered by Indonesian president Joko Widodo (Jokowi) at his inauguration and speeches on visions during his future administration, this study will highlight the power relations and language expressed in Jokowi's speech. This analysis is considered significant because it attempts to bridge linguistic and social theories, linking considerations of language use, attitudes, and beliefs with power.

Several studies take analytical data related to the president of the Republic of Indonesia, such as Hasanah \& Mardikantoro (2017), Sumarti (2010), Irsyadi (2019), and Sofyan \& Subaharianto (2016). In Hasanah \& Mardikantoro's (2017) and Irsyadi's (2019) studies, the data takes the form of news texts about the electability and the first hundred days of Joko Widodo's rule in online news media. Meanwhile, in their research, Sumarti (2010) and Sofyan \& Subaharianto (2016) used data in the form of presidential speeches of Susilo Bambang Yudhoyono and Joko Widodo. Each study mentioned above has a different research focus, but both use critical discourse analysis. Some focus on the style of discourse, political strategy, and the electability of the president. However, there is still little research that analyzes the modalities in the president's speech, especially the power modalities in President Joko Widodo. Therefore, the authors are interested in examining the modalities of power in President Joko Widodo's speech. Because one of the approaches used by politicians in projecting power is the use of linguistic modalities, this analysis is deemed necessary to reveal how the government uses modalities to express its power.

\section{METHOD}

This article investigates the Indonesian president's speeches at the time of the presidential and vice-presidential inauguration 2019-2024 and the Indonesian vision of Jokowi's speech. It aims to reveal the power relations expressed through the linguistic features of the two speech texts. This research is descriptive-interpretive within the framework of discourse analysis.

The data used is in the form of the speech text of President Joko Widodo, which was obtained via the internet, from the Kompas.com site, which indeed published the complete manuscript of the President's speech. The speech has also been broadcast live by several TV stations in Indonesia and published on the Indonesian presidential secretariat official youtube account. The data consists of President Joko Widodo's first speech as the elected president in the 2019 election, delivered at the Sentul International Convention Center, Bogor; and the speech at the 2019-2024 presidential and vicepresidential inauguration before the People's Consultative Assembly (MPR RI) members, attended by state officials, state leaders, heads of state and government as well as special representatives from other countries.

The data analysis procedure was carried out in several stages. In the first stage, data taken from speech texts are grouped based on modalities representing power projections referring to Alwi (1990). Then the second stage, each data is given a unique code, such as ST coding for (text source), ND coding for (data number), and NR coding for (reference number). This Indonesian modality is analyzed using a three-dimensional model of Fairclough's critical discourse analysis (1995). The first stage of analysis is the description stage that discusses the language (modality) used by Joko Widodo in his speech. At this stage, the analysis emphasizes the surface meaning or actual meaning, while the interpretation and explanation stage discusses the meaning of utterances based on the existing context and analyzes the president's power by trying to project it. The analysis departs at the micro-to-macro level to establish the relationship between the text and its formal aspects with society. The analysis was carried out from textual analy sis to a broader scope of social practice. The micro to macro-level analysis is carried out simultaneously by examining the data to achieve the research objectives. Using this view, each linguistic modality can be 
adequately explained in terms of its social, historical, and political context.

\section{FINDING AND DISCUSSION \\ The Use of Modality in the Speech}

Based on the analysis of modalities Based on the analysis of linguistic modalities, the modality used in this context is that in the text of Joko Widodo's presidential speech, including ingin, mau, ajak, semoga, tolong, minta, bisa, dapat, akan harus, pasti, yakin, jangan, and mampu. In Fairclough's microanalysis (1995), several aspects are to be analyzed, one of which is modality. Fairclough (1995) views modality as forming social relationships capable of interpreting attitudes and power. For example, the use of modalities in leadership discourse, in general, will be found in the majority of modalities that have the meaning of orders and demands such as mesti, harus, perlu, hendaklah, and others.

The findings show that the president uses all modality forms in his speech, ranging from epistemic modalities, professional modalities, deontic modalities, and dynamic modalities. The modalities used are analyzed based on their grammatical features' relational values, which are related to their social function.

Table 1. The use of modalities in the speech

\begin{tabular}{|c|c|c|}
\hline Modality & Frequency & Meaning \\
\hline \multicolumn{3}{|c|}{ Intensional Modalities } \\
\hline Ingin & 4 & Desire \\
\hline Mau & 1 & Will \\
\hline Akan & 29 & Desire, will, will \\
\hline Ajak & 1 & Invitation / appeal \\
\hline Tolong & 1 & Request \\
\hline Minta & 2 & Request \\
\hline \multicolumn{3}{|c|}{ Epistemic Modalities } \\
\hline Bisa & 1 & $\begin{array}{l}\text { Tentative potential / } \\
\text { possible abilities, } \\
\text { impossibilities, } \\
\text { colloquial language }\end{array}$ \\
\hline Akan & 6 & $\begin{array}{l}\text { Predictions, support } \\
\text { commitments, } \\
\text { conditional } \\
\text { consequences }\end{array}$ \\
\hline Harus & 1 & $\begin{array}{l}\text { Strong } \\
\text { need/obligation, self- } \\
\text { confidence }\end{array}$ \\
\hline Pasti & 9 & Certainty, belief \\
\hline
\end{tabular}

Yakin 2 Certainty, belief

\begin{tabular}{|c|c|c|}
\hline \multicolumn{3}{|c|}{ Deontic Modalities } \\
\hline Jangan & 9 & Command / inhibition \\
\hline Harus & 47 & $\begin{array}{l}\text { Need/obligation, self- } \\
\text { confidence }\end{array}$ \\
\hline \multicolumn{3}{|c|}{ Dynamic Modalities } \\
\hline Bisa & 4 & $\begin{array}{c}\text { Ability, } \\
\text { encouragement for } \\
\text { others }\end{array}$ \\
\hline матри & 4 & $\begin{array}{c}\text { Ability, } \\
\text { encouragement for } \\
\text { others }\end{array}$ \\
\hline Dapat & 1 & $\begin{array}{c}\text { Ability, } \\
\text { encouragement for } \\
\text { others }\end{array}$ \\
\hline
\end{tabular}

Source:

In the text of President Jokowi's speech, modalities are used to express knowledge, belief, and assessment of certain things. As Coates (1983, p. 18) argues, modality is concerned with the speaker's assumptions or likelihood judgments and, in most cases, it indicates the speaker's belief or distrust in the truth of the proposition expressed.

Jokowi rarely uses bisa modality in his speeches. Of the analyzed speech texts, there is only one expression of the linguistic modality of bisa. Example (1) provides an insight into how the president uses the epistemic speculative modality bisa in his speech to reveal the tentative possibilities based on his assessment, especially on the use of vocational training and vocational school related to the quality of his education will continue to be improved.

(1) Bisa dipastikan pentingnya vocational training, pentingnya vocational school.

(It can be ascertained the importance of vocational training, the importance of vocational school).

Other expressions of this type of epistemic modality appear in Examples (2) and (3).

(2) Saya yakin, kita semua berkomitmen untuk meletakkan demokrasi yang berkeadaban, I am sure we are all committed to putting down a civilized democracy,

(3) Kita harus yakin bahwa kita bisa menjadi salah satu negara terkuat di dunia! 
We have to believe that we can become one of the strongest countries in the world!

In examples (2) and (3), Jokowi uses the modality yakin. Yakin expresses epistemic certainty or belief, a powerful modality. Using yakin provides a definite judgment from the speaker's point of view. It indicates that there is an objective use of modality or an individual's personal opinion and belief. It is relevant to the study of Liu \& Luo (2019).

In this regard, Jokowi firmly stated the conclusion that must be followed by everyone. Yakin refers to an epistemic belief, a modality as strong as possible compared to modality as possible. In both cases, modality can be used when the president is confident in his judgment about a particular case.

Other expressions of the epistemic modality of certainty appear in Examples (4) to $(10)$.

(4) Bisa dipastikan pentingnya vocational training, pentingnya vocational school. It can be ascertained the importance of vocational training, the importance of vocational school.

(5) Hati-hati! Ke depan, ke depan, saya pastikan akan saya kejar!

Be careful! Going forward, going forward, I'm sure I'll chase!

(6) Kalau pola pikir, kalau mindset birokrasi tidak berubah, saya pastikan akan saya pangkas!

If the mindset, if the bureaucratic mindset doesn't change, I'll make sure I'll cut it!

(7) Begitu saya lihat tidak efisien atau tidak efektif, saya pastikan akan saya pangkas dan copot pejabatnya!

As soon as I see it is inefficient or ineffective, I make sure I will cut and remove the officials!

(8) Kalau ada lembaga-lembaga yang tidak bermanfaat dan bermasalah, saya pastikan saya bubarkan!

If there are institutions that are useless and problematic, I make sure I dissolve them!

(9) Karena, setiap rupiah yang keluar dari $A P B N$, semua harus dipastikan memiliki manfaat ekonomi!
Because every rupiah that comes out of the APBN, all must be ensured to have economic benefits!

(10) Saya pastikan, sakali lagi saya pastikan, pasti saya copot.

I make sure, once again I confirm, I will definitely take it off.

In Examples (4) to (10), Jokowi uses modality pasti. Like modality yakin, modality pasti expresses epistemic certainty or confidence, a powerful modality. Jokowi firmly stated the conclusion that must be obeyed by everyone. From the choice of modality, it shows that Jokowi exerts his power.

Another modality used in the president's speech is modality e harus. In its expression, modality harus can be categorized as an epistemic or deontic modality. In general, the deontic modality harus is used when the speaker is not in a position to or may not even want to require actualization, for example when making requests, advice, or giving suggestions (Collins, 2009, p. 35). To exercise power, Jokowi put forward his idea of using modality harus, which refers to an obligation or something that needs to be done to achieve specific goals.

(11) Kita harus menyadari, kita harus sadar semuanya bahwa sekarang kita hidup dalam sebuah lingkungan global yang sangat dinamis!

We have to realize; we must all be aware that we now live in a very dynamic global environment!

(12) Oleh sebab itu, kita harus mencari sebuah model baru, sebuah cara baru, nilai-nilai baru dalam mencari solusi dari setiap masalah-masalah yang kita hadapi, dengan inovasi-inovasi.

Therefore, we must look for a new model, a new way, new values in finding solutions to every problem we face with innovations.

The subjective modality of harus in (11) and (12) provides advice or an obligation to be aware of the era's dynamic developments. President pronounces modality harus as the deontic modality, an undetermined consideration of what can be considered and desired rationally. 
Jokowi also uses the modality jangan, which refers to something that does not need to be done or a prohibition on something.

(13)Itu yang harus dijaga betul! Jangan sampai ada stunting.

That must be appropriately guarded! There should be no stunting.

(14)Jangan sampai ada kematian ibu, kematian bayi yang meningkat. Tugas besar kita ada di situ!

There should be no maternal mortality, increased infant mortality. Our big task is there!

(15)Jangan ada yang alergi terhadap investasi.

No one should be allergic to investing.

(16)Asal jangan oposisi yang menimbulkan dendam. Asal jangan oposisi yang menimbulkan kebencian, apalagi disertai dengan hinaan,

As long as the opposition does not create revenge. As long as the opposition does not cause hatred, let alone be accompanied by insults,

(17)Jangan ragu! Jangan pernah ragu untuk maju!

Don't hesitate! Never hesitate to move forward!

(18)Jangan sampai kita terjebak dalam rutinitas yang monoton.

Don't get caught up in a monotonous routine.

(19)Jangan lagi kerja kita berorientasi pada proses, tapi harus berorientasi pada hasil, hasil yang nyata.

Our work should no longer be processoriented, but must be result-oriented, tangible results.

In Examples (13) to (19), Jokowi uses the modality jangan, which generally expresses a prohibition against something not to be done. In this example, modality jangan also expresses the prevention of something that should not happen. The speaker uses his power to convey ideas in the form of a prohibition order.

However, this example shows that the word jangan expresses a sign of prohibition and emphasizes the importance of a statement. Similarly, Irham's (2018) study also found a shift in the use of particles in the Madurese language, namely as a barrier marker and as a firm marker. These findings indicate a topic shift when used in interrogative sentences, provide warnings or prohibitions for imperative sentences, and emphasize the importance of statements in declarative sentences.

The epistemic modality harus implies the speaker's self-confidence (Coates, 1983, p. 4; Huddleston \& Pullum, 2002, p. 181). The speaker seems convinced that the conclusions presented are the only ones possible.

\section{(20) Persatuan dan kesatuan bangsa adalah pengikat utama dalam meraih kemajuan itu. Persatuan dan persaudaraan harus terus diperkuat. Hanya dengan bersatu, kita akan menjadi negara yang kuat dan disegani di dunia. \\ National unity and integrity are the main binding agents in achieving this progress. Unity and brotherhood must continue to be strengthened. Only by being united will we be a strong and respected country in the world.}

In example (20), Jokowi shows confidence in the achievement of something. The President presented and convinced the audience of the best way to achieve specific goals. Each appearance of the epistemic modality harus described above indicates the speaker's belief in what he believes to be the only solution. The use of modality harus confirms the speaker's belief in concluding and providing solutions or ways to overcome specific problems.

Linguistic modality akan, which can be categorized as an intentional modality or epistemic assumption modality, is also used in presidential speeches. Modality akan, in the form of negation or the passive form, is scattered in the text. Akan in the text has references to central, conditional, and future epistemic consequences (Huddleston \& Pullum 2002).

(21) Jangan ada yang alergi terhadap investasi. Karena dengan cara inilah lapangan pekerjaan akan terbuka yang sebesar-besarnya.

No one should be allergic to investing. Because in this way, employment 
opportunities will open as much as possible.

(22) Bagi yang tidak serius, saya tidak akan memberi ampun. Saya pastikan, sekali lagi saya pastikan, pasti saya copot.

For those who are not serious, I will not forgive. I make sure, once again I confirm, I will definitely take it off.

In example (21), akan shows us a reasonable belief: jobs will be abundant. Jokowi, at this time, is expressing his stance on the plan to invite numerous possible investments to create jobs. The speaker makes this statement based on the rationality of the impact of investing. Thus, akan presents an idea of his belief in the program, even though only his own beliefs are based on future views. So, it is not an attempt to convince the audience to believe that his statement is the only way to ensure the program's success.

Whereas in example (22), it is a form of negation of akan, which is used to express a warning that is mandatory to follow. The President expressed his attitude to remove office for those who are not serious about running his program. There is another expression that emphasizes the future, as in the example (23).

(23) Hati-hati! Ke depan, ke depan, saya pastikan akan saya kejar! Akan saya kejar, akan saya kontrol, akan saya cek, dan akan saya hajar kalau diperlukan!

Watch Out! Going forward, going forward, I'm sure I'll go after! I'll chase, I'll control, I'll check, and I'll beat up if necessary!

Another example of modality akan used in a presidential speech is as follows.

(24) Hanya dengan bersatu, kita akan menjadi negara yang kuat dan disegani di dunia. Only by being united will we be a strong and respected nation in the world.

(25) Saya yakin, kita semua berkomitmen untuk meletakkan demokrasi yang berkeadaban, yang menjunjung tinggi kepribadian Indonesia, yang menjunjung tinggi martabat Indonesia, yang akan membawa Indonesia menjadi Indonesia maju, adil, dan makmur.
I am sure that we are all committed to putting down a civilized democracy, which upholds the Indonesian personality, which upholds Indonesia's dignity, which will lead Indonesia to become an advanced, just, and prosperous Indonesia.

Two examples of modality akan are found in Examples (24) and (25). Akan is not always the future but will also reveal desires and predictions (Azar, 2002, p. 52). It is understood that the use of modality akan reveals that Jokowi is making predictions for the future. He predicted that Indonesia would become a strong and prosperous country in the future based on his perspective and beliefs. Although this statement is only a prediction, it is made based on Jokowi's aspirations in realizing Indonesia in the future. Therefore, Jokowi expressed hope that Indonesia would become a strong and prosperous country.

Another use of modality akan is to express willingness, as in the following sentence:

(26) Pembangunan infrastruktur akan terus kita lanjutkan! Akan terus kita lanjutkan! We will continue to build infrastructure! We will continue!

For example (26), linguistic modalities express his willingness to continue with infrastructure development. As president, he must have the will to support programs that improve the country's progress and welfare. In this example, the modal akan refers not to the future but also to the speaker and audience's will.

Huddleston \& Pullum (2002) suggest that using modality akan refers to conditional consequences.

(27) Kalau kita tidak pindah, ini akan menjadi kebiasaan, di titik itu lagi. Dan itu akan dianggap sebagai aturan. Dan kalau diteruskan bahkan nantinya akan dijadikan seperti undang-undang." Dudu knya apa, berdirinya di situ terus. In $i$ yang namanya monoton dan rutinitas. If we don't move, it will become a habit, at that point again. And that will be considered the rule. Moreover, if it is continued, it will even be made into a 
law. " What are you sitting, standing there continuously. This is called monotony and routine.

Modality akan in (27) conveys the consequences of a presidential protocol, which is considered a rigid custom. In both the first, second, and third sentences, modality akan refers to the consequences of the presidential protocol that must be followed. The president wanted to express his idea regarding the proposed innovation that the government is expected to work not in a process-oriented, but on tangible results. It is hoped that, by providing real-world examples, the audience will readily agree with the proposed idea.

The president also uses the bisa and mampu modality in his speech. These two modalities can express informal polite requests, informal permission, ability or possibility, and impossibility in negative forms (Azar, 2002). In Jokowi's speech, the modalities bisa and dapat mostly refer to ability. This type of modality falls into the dynamic modality category.

(28) Kita akan mengelola talenta-talenta yang hebat yang bisa membawa negara ini bersaing secara global.

We will manage great talents who can bring this country to compete globally.

(29) Namun, perlu saya ingatkan bahwa mimpi-mimpi yang besar hanya bisa terwujud jika kita bersatu! Jika kita optimistis! Jika kita percaya diri!

However, I need to remind you that great dreams can only come true if we are united! If we are optimistic! If we believe in ourselves!

(30) Kita harus yakin bahwa kita bisa menjadi salah satu negara terkuat di dunia!

We have to believe that we can become one of the strongest countries in the world!

(31) Ucapan terima kasih juga saya sampaikan kepada seluruh lembaga-lembaga negara, kepada jajaran aparat pemerintah, TNI dan Polri, serta seluruh komponen bangsa yang turut mengawal pemerintahan selama 5 tahun ini, sehingga dapat berjalan dengan baik.

I would also like to express my gratit u de to all state institutions, the government apparatus, TNI, and Polri, and all components of the nation who have participated in safeguarding the government for the past five years.

In examples (28) through (30), modality bisa shows capabilities and encourages others to become strong and competitive countries globally. Whereas in example (31), the president uses modality dapat, which also shows ability. In the context of the sentence expressed, the expression of the capabilities contained in modality dapat is addressed to the ranks of state institutions and officials who have helped the president carry out his duties during the five years of his administration. The real context is that the elected president is the incumbent presid ent. Jokowi also uses modality bisa - in its negative form - to express abilities and thus encour age others in his speech, as follows:

(32) Membangun SDM yang terampil, menguasai ilmu pengetahuan dan teknologi. Mengundang talenta-talenta global untuk bekerja sama dengan kita. Itu pun, tidak bisa diraih dengan caracara lama. Cara-cara baru harus dikembangkan.

Developing skilled human resources, mastering science and technology, and inviting global talents to work with us. That, too, cannot be achieved by old methods. New ways must be developed.

The use of the negative form of tidak bisa in the third sentence (32) indicates that it is irrelevant if the old method is still used to develop human resources quality. A new, more innovative way of developing human resources is needed. Jokowi tried to invite the use of more recent methods for Indonesia to move forward. He uses supporting sentences when trying to compare discourses about expressed ideas.

Other types of dynamic modalities also come into operation in presidential speeches. The modality is in the form of mampu linguistic modality, which is used to sh ow the ability to something.

(33) Indonesia yang menguasai ilmu pengetahuan dan teknologi kelas dunia, Indonesia yang mampu menjaga, 
mengamankan bangsa dan negara dalam dunia yang semakin kompetitif.

(34) Karena, kita mampu jika kita bersatu!

(35) Tapi akan menjadi kesempatan besar, peluang besar, jika kita mampu membangun SDM yang unggul.

Examples (33) through (35) offer other examples of the modality mampu in the presidential speech text. In this example, there is a further explanation that Indonesia can become a developed country. Jokowi tried to convince the audience about Indonesia's potential to become a world civilization armed with Pancasila, which upholds unity. He explained what was meant by advanced Indonesia.

The final modality expression used in President Jokowi's speech was to express preferences, requests, unfulfilled desires, repeated actions in the past, or politely replace 'wants' when followed by 'like' (Azar, 2002 , p. 200). It is known as an intentional modality. Linguistic modality ingin is an intentional assumption modality used in presidential speeches in either negative or positive forms. This modality is related to wishes, hopes, invitations, and omissions, as well as requests. This modality is characterized by lexical elements such as ingin, mau, tolong, mari, ayo, and silakan (Alwi, 1990).

(36) Kita ingin memberikan prioritas kepada pembangunan sumber daya manusia kita.

We want to give priority to the development of our human modality.

(37) Kita ingin bersama dalam Bhinneka Tunggal Ika, dalam keberagaman.

We want to be together in Bhinneka Tunggal Ika, in diversity.

(38) Oleh karena itu, lima tahun ke depan yang ingin kita kerjakan......

Therefore, the next five years that we want to work on

(39) Kita juga tidak ingin ada lagi pola-pola kerja linier.

We also don't want linear work patterns anymore.

In examples (37) to (39), Jokowi uses modality ingin. Modality ingin expresses desire or desire. The use of modality ingin explains the desire for future power in the form of ideas expressed by the president through his powers. Example (39) is a form of desire modality in the form of negation. The context in sentence (39) is that the president intends that in the future, the work pattern of government is more inclusive and not monotonous so that it can provide excellent and maximum service to the community.

Another expression of the use of the intentional modality of desire appears in example (40).

(40) Dan saya tidak mau birokrasi pekerjaannya hanya sending-sending saja. Moreover, I don't want the bureaucracy only to send my work.

In example (40), Jokowi uses the modality mau. Similar to modality ingin, modality mau expresses willingness or desire for something to be achieved. However, in that sentence, the modality mau is negative. As with the positive form, its function is to express an attitude of desire. From the choice of modality, it shows that Jokowi is using his power.

Another type of intentional modality is also used in presidential speeches. The modality is in the form of linguistic modality minta and tolong. Both modalities are used to show a demand for something.

(41) Kalau pola pikir, kalau mindset birokrasi tidak berubah, saya pastikan akan saya pangkas! Tolong ini dicatat. Karena kecepatan melayani, kecepatan memberikan izin, menjadi kunci bagi reformasi birokrasi kita.

If the mindset, if the bureaucratic mindset doesn't change, I'll make sure I'll cut it! Please note this. Because the speed of serving, the speed in giving permission, is the key to reforming our bureaucracy.

(42) Saya akan minta untuk disederhanakan menjadi 2 level saja, diganti dengan jabatan fungsional yang menghargai keahlian, menghargai kompetensi.

I would ask that it be simplified to just two levels, replaced by functional positions that value expertise, respect competence. 
(43) Saya juga minta kepada para menteri, para pejabat, para birokrat, agar serius menjamin tercapainyatujuan program pembangunan.

I also ask ministers, officials, and bureaucrats to guarantee the development program's goals seriously.

Example (41), Jokowi uses modality tolong. The president uses this modality to show demand. The President expressed assertiveness as part of his power by asking for previously disclosed statements to be recorded. The modality minta is also used in the president's speech. This modality is used in examples (42) and (43). Similar to the tolong modality, the minta modality is used by Jokowi to express requests. The President requested that the summarization and enforcement levels are within the bureaucratic level. The President also asked state officials who assisted the president's performance to be earnest in carrying out the announced duties and programs.

\section{(44) Pemerintah akan mengajak DPR untuk menerbitkan dua undang-undang besar.}

The government will invite the DPR to issue two major laws.

The modality mengajak is also used in the text of presidential speeches. Modality mengajak is also an intentional modality. In example (44), the president uses the mengajak modality to express an invitation/appeal to the DPR (People's Representative Assembly) to fix laws related to economy regulations that can hinder job creation, UMKM, and many more. Here the president uses his power by using the modality mengajak in his speech.

Based on the above discussion, it can be understood that every single linguistic modality used in the president's speech has a specific purpose and expresses certain ideas that seek to influence the audience to agree or follow his opinion. The modalities used in speech can depend on the possible judgments from his point of view, or predictions, the judgments expressed, the conditional consequences, commitments, abilities, impulses, potential, and tentative abilities, impossibilities, colloquial language, musts or obligations, all of which express worthiness, level of self-confidence, desire, and willingness. Jokowi tries to express domination, supremacy, superiority, authority, and power, especially particular views or beliefs. Through the language used in his speech, Jokowi strives to guide people's beliefs and minds and control them.

Jokowi has the opportunity to use his strength through his speeches in meetings and hearings attended by state officials. He uses available resources to control others, as explained by linguistic expressions in his speech.

These speeches were delivered in the domestic forum's situational context, which was even attended by heads and representatives from other countries. One of the speeches was delivered at the inauguration ceremony of President Joko Widodo. Thus, it can be assumed that the people involved in the arena are interested in it. This forum discusses the Indonesian vision expressed by Jokowi. The President delivers a speech in Indonesian, which is official and standard. Jokowi often uses linguistic modalities in the speeches he delivers at forums. These modalities should be examined separately to build the network and finally draw general conclusions about their contribution to the text.

\section{Power through the expression of modality}

From the previous discussion, it can be concluded that the use of modalities can project strength. Where Jokowi delivered his speech, attended by state officials, state officials, heads, and envoys from various countries, there may be many differences. To express his strength in front of the audience, he conveyed his ideas about the future's vision and work program using various modalities. In this case, President Joko Widodo is in his situation and institution as president by conveying his ideas about the vision and w ork program. In the critical discourse analysis concept at the macro level by Fairclough (1995), there are three aspects of analysis, namely situational, institutional, and social.

\section{Obligation and Necessity}

The use of the obligation or necessity modality is one indication of power. Van Dijk (2008, p. 37) states that those in power have direct control over actions that can be 
achieved through pragmatic discourse, which functions as orders, directions, instructions, suggestions, and recommendations. Therefore, it is clear that the expression of obligations and needs through linguistic modalities supports power in the discourse or speech produced by the president.

Obligations or necessities in the speech text are presented through the modalities harus, yakin, and pasti. It can be understood that power can be projected through the expression of necessity. Command powers need only be subject to particular cases, for example when agents are hierarchically superior to others. The source of power is relative and not completely attached to a person. A person or group can only exercise control in certain situations.

Jokowi can show his confidence and oblige others to prioritize the country's progress and welfare with good performance. In his speech, it can be understood that he used modality harus to express a need for all people, especially officials who serve the public. It is understood that his power is not absolute and still involves himself in asking others to follow his exhortations.

Jokowi stipulates the obligation for all government officials and officials to adopt a strategic mindset and try new approaches when carrying out their duties and programs. Its direction is the linguistic realization that depends most on the strength and most clearly of the coercive function (Chilton \& Schäffner, 1997, p. 219). Power can also be expressed by using titles by making prom ises or threats. This positive self-presentation strategy is also a way to express power (Vadai, 2016).

\section{The modality that expresses the speaker's view of the future}

One of the ways Jokowi shows power to his audience in his speech is using the possibility of modality akan. Sometimes, this modality indicates that the speaker lacks the confidence to say something directly. Modality akan is used to avoid dictating ideas as if the speaker is asking the audience to agree with the idea. It does not imply that the audience and speaker are equal.

Modality akan can be categorized as a moderate probability because the speaker is unsure of what will happen in the future. In
Jokowi's case, he argued over the possibility that if the monotonous presidential protocol program became a habit, it would be impossible if it would turn into rules and even the rule of law, whereas he wanted something innovative and not rigid. His strength is rooted in forward-thinking assumptions and a strong determination to make a change that is more results-oriented than process-oriented. Relying on rationalization towards the future, he persuaded the audience by providing examples and plausible arguments to bring about the changes he has planned, which would undoubtedly bring Ind onesia's country to the fore.

Expression of strength in speech through the use of modality akan is linked to future ideas. However, it has been characterized and considered in this study as a subcategory of epistemic prediction. In this case, Nordberg (2010) states that modality akan can be considered confidence related to predictions about something's behavior. In the context of Jokowi's strength, modality akan is used as an epistemic prediction based on personal experience.

\section{The modality that expresses the speaker's evaluation}

Jokowi does not use modality mungkin at all, but here Jokowi uses modality bisa, an epistemic speculative modality. This modality can express the speaker's abilities, such as when expressing something as an encouragement to the audience.In this regard, this modality is often used when referring to Jokowi's conclusions. It is in line with Nuyts' (2006, p. 31) statement that, for epistemic modalities, the speaker himself knows the evidence and draws conclusions from it.

His statements were supported by convincing and rational arguments that come from previous observations. By presenting an example, he invites his audience to believe and continue efforts to realize all the proposed ideas and support each other without exception.

The modality that expresses the speaker's abilities and capacities

Besides, Jokowi uses modalities to express his belief in audience members' capabilities and capacities, including state officials who will carry out community service 
programs. Mostly based on their own will and experience. Using his background experience and knowledge, he must also have power over others. Thus, it is easier for him to influence other people to imitate, follow, and produce practical actions to innovate and carry out better performance to make Indonesia better and more prosperous. As stated by Collins (2009), the ability is based on agents who have the potential to take action. Jokowi's belief in audience ability is also based on the potential actions he has had.

\section{CONCLUSION}

There are thirteen types of modality used in the text of President Joko Widodo's speech: ingin, mau, akan, ajak, tolong, minta, pasti, yakin, harus, bisa, jangan, mampu, and dapat. Regarding the notion of power that the president tries to use, each modality expresses his weakness and power from various sources of strength.

Regarding modalities, Jokowi often u s es potent modalities, for example, modality harus, to convince the audience to follow or take the actions he proposed based on his prior experiences. Likewise, his suggestions are based on his previous experiences as president of Indonesia. Therefore, it uses such a modality where it has power based on real examples. A weak modality is used when he describes and expresses personal opinions or judges something from his perspective. Nonetheless, he consistently used examples and future expectations to demonstrate strength and persuadeaudiences.

Jokowi delivers his speech confidently whenever he considers himself to have power, such as legitimacy as Indonesia's president to create a better Indonesia. Jokowi tried to convince his audience. $\mathrm{He}$ also gave appreciation to people who had helped him realize a work program for a better Indonesia.

From the above discussion, it can be concluded that, through his speech, Jokowi is projecting his authority to equalize himself and officials and even other Indonesian people. Implicitly, he tries to project his future programs and ideas in governing the Indonesian state through the choice of modalities in his speech.

\section{REFERENCES}

Alwi, H. (1990). Modalitas dalam Bahasa Indonesia. Seri ILDEP. Yogyakarta: Penerbit Kanisius.

Azar, B. S. (2002). Understanding and Using English Grammar. 3rd ed. New York: Longman.

Chilton, P. (2006). Analysing Political Discourse: Theory and Practice. London: Routledge.

Chilton, P., and Schäffner, C. (1997). 'Discourse and politics.' In: van Dijk, T. A. (ed.) Discourse Studies: A Multidisciplinary Introduction. London: SAGE Publications.

Clark, U. (2007). Studying Language. Basingstoke: Palgrave Macmillan.

Coates, J. (1983). The Semantics of the Modal Auxiliaries. London: Croom Helm.

Collins, P. (2009). Modals and Quasi-modals in English. Amsterdam: Rodopi.

Fairclough, N. (1995). Critical Discourse Analysis. London: Longman.

Fowler, R. (1985). 'Power.' In van Dijk, T. A. (ed.) Handbook of Discourse Analysis. Volume 4: Discourse Analysis in Society. London: Academic Press.

Hasanah, A., \& Mardikantoro, B. (2017). Konstruksi Realitas Seratus Hari Pertama Pem erinta han Jokowi-Jusuf Kalla di Media Online: Analisis Wacana Kritis Model Norman Fairclough Abstrak. Seloka: Jurnal Pendidikan Bahasa Dan Sastra Indonesia, 6(3), 233-243. 
Huddleston, R., and Pullum, G. K. (2002). The Cambridge Grammar of the English Language. Cambridge: Cambridge University Press.

Irham, I. (2018). Evaluating the pragmatic particle jâ'in a Madurese spoken corpus. Indonesian Journal of Applied Linguistics, 7(3), 638-649.

Irsyadi, A. N. (2019). Gaya Wacana Media Dalam Kontruksi Media Tentang Pemberitaan Elektabilitas Presiden. LiNGUA: Jurnal Ilmu Bahasa Dan Sastra, 14(1), 197-204. https://doi.org/10.18860/ling.v14i1.6425

Liu, F., \& Luo, Q. (2019). Gradability, Subjectivity and the Semantics of the Adjectival zhen 'real'and jia 'fake'in Mandarin. In Workshop on Chinese Lexical Semantics (pp. 165 -172). Springer, Cham.

Nordberg, T. (2010) Modality as Portrayed in Upper Secondary School Textbooks: A Corpus-based Approach. Unpublished Master Thesis. Helsinki: University of Helsinki. Online document. <https://helda.helsinki.fi/handle/10138/19357>.

Nuyts, J. (2006). 'Modality: Overview and linguistic issues.' In: Frawler, W. (ed.) The Expression of Modality. Berlin: Mouton de Gruyter.

Reid, S. A., and Ng, S. H. (1999). 'Language, power, and intergroup relations.' Journal of Social Issues 55(1), 119-139. DOI: 10.1111/0022-4537.00108.

Saville-Troike, M. (2003). The Ethnography of Communication: An Introduction. Oxford: Blackwell Publishing Ltd.

Sofyan, A., \& Subaharianto, A. (2016). Analisis Wacana Politik Joko Widodo Saat Pemilihan Presiden 2014. Universitas Jember.

Sornig, K. (1989). 'Some remarks on linguistic strategies of persuasion.'In: Wodak, R. (ed.) Language, Power, and Ideology. Amsterdam: John Benjamins.

Sumarti, E. (2010). Analisis Wacana Kritis Strategi Politik Penggunaan Bahasa dalam Pidato $\begin{array}{llll}\text { Presiden Susilo Bambang } \quad \text { Yudhoyono. } & \text { LITERA, 9(1), }\end{array}$ https://journal.uny.ac.id/index.php/litera/article/viewFile/1215/1028

Suryawinata, Z. (1990). Pendidikan Bahasa dan Pembangunan. Malang: IKIP Malang.

Thomas, L. and Wareing, S. (eds) (2003). Language, Society, and Power. An Introduction. London and New York: Routledge.

Vadai, K. (2016). 'Critical discourse analysis in progress: The power, ideology, and manipulation identification (PIMI) model.' Alkalmazott Nyelvtudomány. DOI: 10.18460/ANY.2016.1.004.

van Dijk, T. A. (2008). Discourse and Power. New York: Palgrave Macmillan. 
LiNGUA Vol. 15, No. 2, December 2020 • ISSN 1693-4725 • e-ISSN 2442-3823 